\title{
Analysing the Methods of Agrarian-Economic Terminology Lexicon Enrichment in French
}

ISSN: 2311-8636 (Print)

ISSN: 2312-2021 (Online)

Licensed:

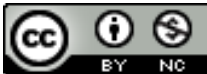

Source of Support: Nil

No Conflict of Interest: Declared

*Email for correspondence:

dvorakova@pef.czu.cz

\section{Milena Dvorakova}

Department of Languages, Faculty of Economics and Management, Czech University of Life Sciences in Prague, Kamýcká 129,165 21 Praha 6, CZECH REPUBLIC

is discussed in more detail. To determine the degree of agrarian-economic terminologization in the French text, a statistical survey was carried out, based on four types of document - a scientific publication, university textbooks, popular professional publication and scientific paper. It would be necessary to use the results of the statistical analysis in the teaching of i.e., languages because the knowledge of the principle of the term formation is one of the prerequisites for mastering the terminology.

Keywords: Word-formation process, specialist terminology, terminologization in French, statistical analysis

\section{INTRODUCTION}

For a specialist lexicon, it is typical that the rules and principles of term formation are substantially by the principles of non-specialist language lexical units' formation. Some wordformation processes and means, however, have a greater functional load in terminology, while others are rare. This fact should be used in teaching foreign languages in vocational schools because the knowledge of the principle of the term formation is one of the prerequisites of mastering the terminology. It can be compared to mathematics, where the student must firs learn a formula and only then, on its basis, he or she may solve examples. Similarly, the knowledge of composites, prefixes and suffixes, abbreviations and multi-word terms allows the identification of semantic concepts. Moreover, it allows the unconscious mastering the principles of creating expressions and revealing the meaning of unfamiliar terminology units, and thus creating the potential vocabulary of the users of professional micro-languages. (BORSUKOVÁ, 1997:66) As in other languages, creating French economic terminology involves all word-formation processes, though not to the same extent.

In the first place, we should mention terminologization, which, causes words of a general language to penetrate into a particular professional terminology after acquiring a specific meaning. The formation of two-word and multi-word names is considered the most productive way of formation. For the most productive way of word, formation must be regarded as the formation of multi-word and multi-word names. In this case, the agrarian-economic terminology is not different from other 
fields, where this method, as well as a derivation procedure, is live and productive. Regarding productiveness, even word composition is equal to the derivation, as, e.g., in agriculture English, as the research by VORÁČEK (1987:27) has shown. In the agriculture German, composition proudly occupies the first place (DROZD 1981: 195), just as in the German economic terminology (HOPPNEROVÁ, 1980:49). Also, abbreviation is represented in all languages.

In French, there have been currently very productive initial acronyms, which have recently become much more frequent than the occurrence of one-syllable abbreviations. The productive process undoubtedly relates to the large amount of two-word and multi-word names, which gained considerable expansion, and which were then shortened and are now commonly used in an abbreviated form as technical terms.

For example:

PIB produit intérieur brut - gross domestic product,

$\mathrm{SA} / \mathrm{f} / \mathrm{C}$ - salaire minimum interprofessionnel de croissance - minimum wage for profession in economic growth,

SARL société á responsabilité limitée - limited liability company,

SEC - Systeme européen de comptes économiques- European System of Integrated Economic Accounts.

French agrarian-economic terminology derives not only from its naming lexical bases but also uses the transposition of words from foreign languages. In this word-formation process, a very clear trend is visible. Earlier transposed terms from the English language used to be unchanged, retaining their spelling and pronunciation. Currently, there is a tendency to take over from English as little as possible, and if yes, the loanwords purposefully resemble French, e.g., conteneur from the English container. Also abundant are calques, e.g., relations publiques (public relations), promotion des Ventes (sales promotion) (VLASÁK, 1995:186). If the borrowed foreign graphical form is retained, there is a tendency to use French pronunciation, such as in management. The assimilation process is characteristic for the current attitude towards loanwords in French. Besides euphemisms, in French agrarian-economic terminology the socalled technocrat jargon is used. Thus, for example, there are seven expressions for social prizes instead of various types of agricultural products:

prix indicatif (céréales et oléagineux) - alleged price (grains and oilseeds),

prix de base (viande de port) - basic price (pork),

prix d' orientation (viande de boeuf) - indicative price (beef),

prix d' objectif (tabac) - target price (tobacco),

prix d'excluse (oeufs et volatiles) - exclusive price (eggs and poultry),

prix de références (vin, fruits et légumes) - market price (wine, fruit and vegetables),

prix de seuil (péche) - threshold price (fishing).

When analyzing ways of enriching the French agrarian-economic terminology, the terminologization will be discussed in detail in this article.

\section{Material And Methods}

\section{Terminologization}

By this word-formation procedure, we understand the use of words common vocabulary for the denomination of specialist terms. Words of ordinary language of the communication become terms if they acquire specifically defined meanings concerning the communication needs of the area in which they are used. In fact, every word general 
vocabulary can be terminologized when it acquired importance in specifically defined areas of expertise in which it is used and included in the system of terminologically relevant professional terminology, in our case, agrarian-economic terminology.

Words formed by terminologization are considered new terms, although there is no new form created by the terminologization, but its refined new meaning. A general word seuil - treshold, was for the area of economics specifically defined, refined - terminologized as follows:

seuil de rentabilité - profitability threshold, the marginal product.

By this refinement in economic terminology, the word detached itself from its counterpart in multi-functional general vocabulary.

To determine a degree of agrarian economic terminologization in French texts, a statistical survey of the group consisting of terms and non-terms was carried out. For this purpose, four types of text were excerpted:

1. a representative scientific publication (Combemal, 1996)

2. a university textbook (Boinon, 1995)

3. a popular-scientific publication (Kroll, 1990)

4. scientific papers ( Notes et Etudes économiques, 1996)

Each text type had a range of 1500 words. Samples were selected from the core part of the above-mentioned texts, relating to economic and financial problems in the agrarianeconomic sector.

ad 1/Les politiques de monnaie forte: de la désinflation compétitive à la récession

ad 2/ Une représentation de la circulation financière dans l'entreprise agricole

ad 3/Le budget de l'agriculture

ad 4/ Evolution du financement communautaire des marchés

The research results are summarized in Table 1.

\section{General economic terms (A), special economic terms (B) and other terms (C)}

The terms are divided into three groups primarily regarding their application in the research and teaching process and after that for sorting the obtained material for morphological analysis that should follow in the next contribution.

\section{General economic terms (A)}

This is a large group of denominations, which are characteristic for professional economic language, but in the relevant field they are words of ordinary language with relevance specifically (economically) defined, e.g.: entreprise, marché, cycle de production, facteur de production, achat, vente, exploitation agricole, reconnaissance de la valeur, profit, perte, etc.

\section{Special economic terms (B)}

These are terms of a certain specialized agrarian-economic sector, in our case finance, e.g.: marge de manoeuvre financière, chiffre d'affaires, valeur ajoutée nette de l'exploitation, marge brute, désinflation compétitive, réduction du taux d'inflation, coüts salariaux, monnaie unique,solde extérieur, déficits publiques, fluctuation des prix, la volatilité des cours, intervention, versement des aides directes, opération d'apurement des comptes, budget recticatif, écart, etc.

\section{Other terms (C)}

These are also specialist terms, but from other fields - in our case, they are mainly agricultural terms of livestock and crop production, e.g.: 
bovins mâles, cultures arables, vaches allaitantes, viande bovine, viande porcine, volailles, etc.

The first two groups may fluctuate, but always regarding economic expressions, used in this case in agrarian texts.

\section{REsults AND Discussion}

Table 1: Statistical analysis of specialized agrarian-economic texts

\begin{tabular}{|l|c|c|c|c|}
\hline 1500 words & $\begin{array}{c}\text { terms in total } \\
\text { share in } \%\end{array}$ & $\begin{array}{c}\text { A } \\
\text { share in } \%\end{array}$ & $\begin{array}{c}\text { B } \\
\text { share in } \%\end{array}$ & $\begin{array}{c}\text { C } \\
\text { share in \% }\end{array}$ \\
\hline Representative scientific publication & 285 & 174 & 111 & 0 \\
& $24 \%$ & $61 \%$ & $39 \%$ & \\
\hline University textbook & 412 & 250 & 135 & 27 \\
& $28 \%$ & $61 \%$ & $33 \%$ & $6 \%$ \\
\hline Popular-scientific publication & 189 & 135 & 44 & 10 \\
& $13 \%$ & $72 \%$ & $23 \%$ & $5 \%$ \\
\hline Scientific papers & 250 & 156 & 79 & 15 \\
& $17 \%$ & $62 \%$ & $32 \%$ & $6 \%$ \\
\hline
\end{tabular}

The exploration of a degree of an overall terminologization showed that the overall percentage of all terms in the texts is approximately around $21 \%$. The exception is the text of a university textbook, with the above-average percentage of terms $(28 \%)$, which is understandable for this type of text understandable.

The lowest percentages was in the text of popular-scientific publication (13\%), which also corresponds to the nature of the text.

The representation of general economic terms with respect to the total number of the terms ranges from $61 \%$ to $72 \%$ - in all cases, it is above average. An exception was the text of popular-scientific publication, where the general economic terms amounted to $72 \%$ of the total number of terms, whereas special economic terms only to $23 \%$. The percentage of special economic terms ranges from $23 \%$ to $39 \%$. The highest percentages are apparent in the text of a representative scientific publication (39\%), lowest in the text of a popularscientific publication (23\%).

\section{The frequency of terms}

As a characteristic phenomenon can be described a great incidence of certain terms in the same text. In this case, we cannot speak about the bad stylistic expression. Repeating the term is not due to the lack of vocabulary, as is the case in general or other non-specialised texts, but it is a must - in most cases, the terms cannot be interchanged using synonyms or other forms as in non-specialised texts. A high frequency of some individual terms is a typical phenomenon of professional style.

It can be stated that in almost all excerpted texts, different, i.e. new terms occurred on the first three pages, and then those same individual terms recurred. Therefore it was finally decided that instead of the originally planned excerpted 2500-3000 words the corpus would be reduced to 1,500 words only, which should be large enough range for the given purpose.

\section{Parts of speech representation within the researched terms}

The research confirmed that, in contrast to other parts of speech, by far the most frequent terms are substantive terms. This is to al large extent caused by nominalisation, which is 
characteristic especially for the agrarian-economic French texts - very often long nominal chains are formed, e.g.:

- opération d'apurement des comptes des exercices antérieurs

- le lieu de réalisation d'un processus de production-commercialisation unitaire

- réduction du taux d'inflation

Adjectival terms take up the second largest group, although in most cases they occur in combination with nouns, e.g.

budget initial, budget recticatif, dépenses provisoires, crédits inscrits, croissance des dépenses communautaires, aides directes, etc.

Adjectival terms occur independently very rarely.

Verbs also function in the analyzed texts as terms, although they may have a possibility of adequate functional usage in terminologies of other fields. The verbs concerned are as follows:

équilibrer, subventionner, financer, exploiter, bénéficier, commercialiser, interventionner, négocier, investir, amortiser, analyser, particulariser, intégrer, valoriser, etc.

Also, a few adverbs were excerpted, playing in the context a role of the economic terms, e.g.: effectivement, ineffectivement, but it is obvious that in this case they have wider application in other fields, and are therefore not included in this survey.

Table 2: Statistical analysis of parts of speech representation within the terms in the text

\begin{tabular}{|l|c|c|c|}
\hline \multicolumn{1}{|c|}{ 1500 word } & substantives: share in \% & Adjectives: share in \% & Verbs share in \% \\
\hline $\begin{array}{l}\text { Representative scientific } \\
\text { publication }\end{array}$ & $69 \%$ & $23 \%$ & $8 \%$ \\
\hline University textbook & $66 \%$ & $21 \%$ & $13 \%$ \\
\hline $\begin{array}{l}\text { Popular-scientific } \\
\text { Publication }\end{array}$ & $65 \%$ & $30 \%$ & $5 \%$ \\
\hline Scientific papers & $60 \%$ & $25 \%$ & $15 \%$ \\
\hline
\end{tabular}

Table 2 shows that in the teaching process it is necessary to pay attention to the parts of speech as both the substantive and adjectival terms which are in abundance, but at the same to the verbal terms, especially in their passive forms.

\section{CONCLUSION}

The conclusion of the research is that the greater the expertise of the text, the greater the representation of special terms.

It is interesting to observe a statistical survey of agricultural terminology in terms of the degree of overall terminologization in the text in other languages. For example, in agriculture English texts in animal production (VORÁČEK, 1987: 29), the total percentage of all terms amounted to $25 \%$. Approximately the same frequency of terms is also present in the texts of German agriculture (DROZD: 1979). The lower percentage of terms in the French economic texts can be explained by the fact that in the economic sphere their many words that transfer from professional to general language.

Regarding implementation of these results into the teaching process, i.e. for teaching practice, it presents a good selection of specialized texts for trainees of Extended Language Study Programme with professional orientation as well as for doctoral studies, where 
working with scientific texts is pivotal. Every doctoral student is supposed to read a scientific text in the range of about 200 pages - the determination of the appropriate foreign language material is done based on scientific cooperation between the students and his or her supervisor in terms of professional focus by the consultant of a specialized foreign language, who assesses the suitability of the material in terms of the text language difficulty and language level of the student. Suitable are representative scientific publications if contemporary and up-to-date texts are available. Otherwise, scientific papers that meet the particular requirement of being up-to-date - which is a crucial requirement in our conditions - also proved useful. In these two types of materials, terms are distributed evenly as opposed to textbooks, where the concentration of terms is higher due to mostly narrower, more specialized orientation, which makes this source more difficult for the students.

Regarding the application of the results obtained in the field of scientific research, it is desirable to consider the analyzed situation in representative scientific publications and scientific papers because it is assumed that during the processing of agrarian-economic texts we will meet with these types of text most often. In these texts, the percentage of special agrarian-economic terms is the highest (39\% and $32 \%$ of the total number of terms).

\section{REFERENCES}

Boinon, J.P. (1995) Comptabilité et gestion de l'entreprise agricole, ENESA Dijon.

Borsukova, H. (1997) Determinanty výučby odborného jazyka, sborník: Aplikácia teoretických a praktických poznatkov vo vyučovaní odborného jazyka, Nitra.

Combemale, J. (1996) Direction: Nouvel Manuel des Sciences Économiques et Sociales, RAINELLI: Commerce International, La Découverte.

Drozd, L.(1981) Grundfragen der Terminologie in der Landwirtshaft. In: Fachsprachen, Darmstadt.

Hoeppnerova, V. (1995) Lexikalische Interferenzfehler bei der Aneignung des Wirtschaftsdeutsch, sborník: Odborný jazyk v podmínkách tržní ekonomiky,VŠE Praha.

Kroll, J. (1990) Agriculture - changer politique, Syros/Alternatives Économiques.

Revue notes et études économiques (1996) Vědecké stati, Ministère de l'Agriculture, Paris, ročník č. 1, 2, 3.

Vlasák, V. (1995) La terminologie économique de l’Union européenne, sborník: Odborný jazyk v podmínkách tržní ekonomiky, VŠE Praha.

Voráček, J. (1987) Zemědělská angličtina a slovotvorná analýza její terminologie, VŠZ Praha.

$$
--0--
$$

Publish Online and Print Version Both

Online ISSN: 2312-2021

Google Scholar: https://goo.gl/eozEWi 